\title{
RECEPTION OF ILLUSTRATED PRINTS OF OVID'S METAMORPHOSES IN BOHEMIAN AND MORAVIAN ART: JOHANN JACOB VON SANDRART AND THE JUDGEMENT OF TIRESIAS
}

\author{
RADKA NOKKALA MILTOVÁ
}

\begin{abstract}
One of the major traits of Baroque art in Bohemia and Moravia is its receptive character. In the cycles thematically taken from Ovid's Metamorphoses artists often accurately followed widespread and popular illustrations. My paper focuses on rare example of reception of Metamorphoses edition published by J. J. von Sandrart in Nürnberg 1698. This edition includes several engravings depicting less frequently visualized stories that were followed in stucco decorations in the Silesian chauteau in Kravaře, irrecoverably damaged during a fire in 1937. The discovery of printed model allowed for the identification of all the iconographic motifs in Kravare. The ceiling of the grand hall showed story about the prophet Tiresias. The article analyses visual representations of Judgement of Tiresias as well as its textual interpretations. The stucco ceiling in Kravaře was the only known monumental visual representation of this motif not only in the Central European context, but most probably in all Europe.
\end{abstract}

Keywords: Kravaře; Ovid; Metamorphoses; Tiresias; Baroque art; stucco; iconography; ancient mythology

Referentiality is one of the essential characteristics of Baroque visual art in Bohemia and Moravia. Artists took inspiration from various graphic models which they used as compositional models for their canvas paintings, wall paintings, reliefs and other works of art. When working with motifs from Ovid's Metamorphoses, artists mainly used popular illustrated editions of the work, in Bohemia and Moravia primarily copies of several famous graphic cycles: woodcuts by Virgil Solis, line engravings by Hendrick Goltzius, Crispijn de Passe, Antonio Tempesta, Johann Wilhelm Baur, and also engravings from the 1676 Paris edition or the 1677 Brussels edition of the Metamorphoses. ${ }^{1}$

1 The cycle of 178 woodcuts by Virgil Solis was first printed in 1563 in two Frankfurt editions; the engravings by Hendrick Goltzius were published by his workshop in three waves in 1589-1615; the series of 150 engravings by Crispijn de Passe was used in a 1602 Cologne edition; Antonio Tempesta made a set of engravings for an Antwerp edition published ca 1606; and Johann Wilhelm Baur for a Vienna edition, ca 1639. The Paris edition included prints of 226 engravings by Sébastien Le Clerc and François Chauveau; and the 1677 Brussels edition contained illustrations by Martin Bouche, 


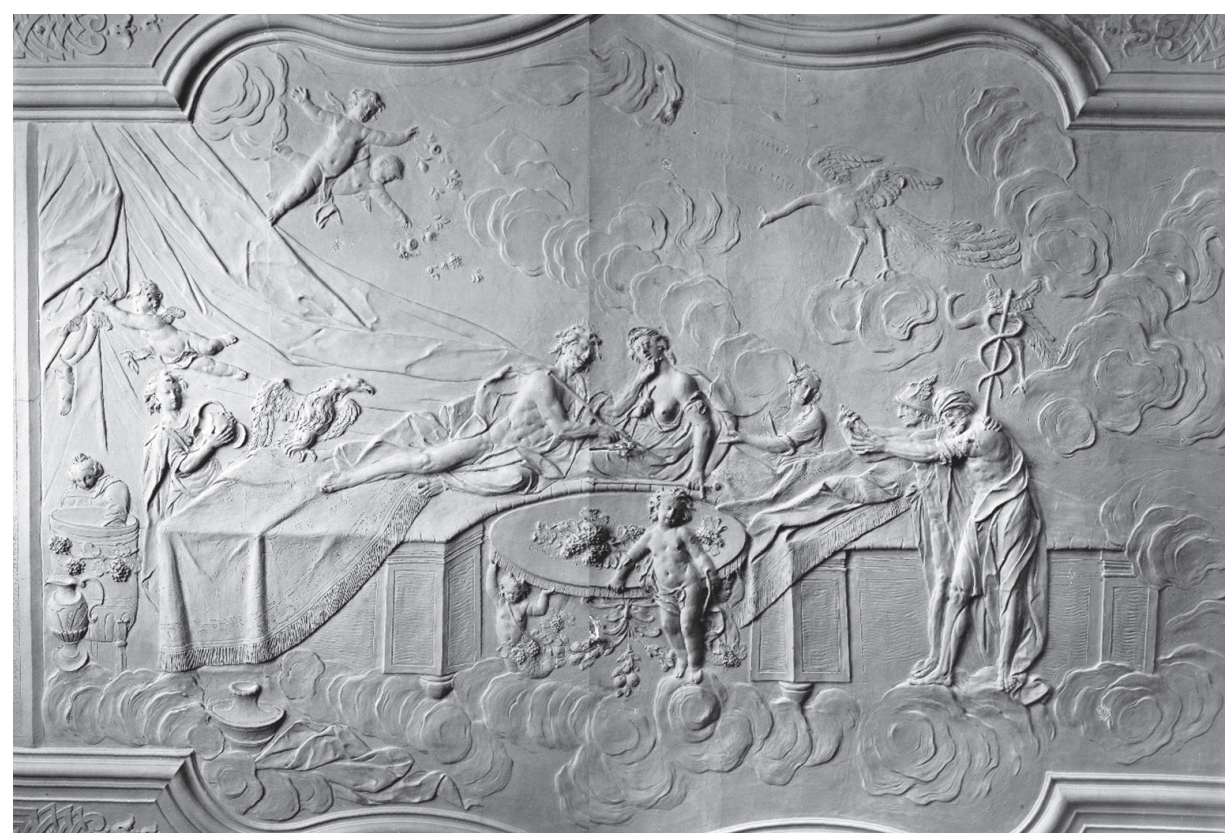

Fig. 1: Judgement of Tiresias, Kravaře, chateau, former stucco decoration of main hall, 1730s. Photo: Silesian Museum, Opava, inv. no. D319 and D320.

Most authors selected pictures from the most famous stories and used them in various combinations in numerous decorative objects. Motifs from less popular stories were replicated rather seldom. Therefore, every artwork showing an aberration from the prevailing praxis attracts attention. Some of these rare depictions of less popular myths from the Metamorphoses were included in the stucco decorations on the ceilings in the Kravare chateau (Deutsch-Krawarn), Silesia, irrecoverably damaged during a fire on 21 January 1937. The original decorations from 1730s, however, were documented in a series of photographs taken during the 1930s. ${ }^{2}$ Interpretation of the scenes in the Kravaře stuccoes was recently considerably facilitated when the source of graphic inspiration, a specific illustrated edition of Ovid's Metamorphoses, was discovered. That allowed for the identification of all the iconographic motifs. ${ }^{3}$ For instance, the decoration in the grand hall of the northern wing ${ }^{4}$ had been titled simply "The feast of the Gods" due to the presence

Peter-Paul Bouche, Frederic Bouttats and Hendrik Abbé. On the reception of these prints in Bohemian and Moravian art, see esp. Miltová (2009: 33-50); Nokkala Miltová (2016: 263-269).

2 The Silesian Museum in Opava, item nos. D317, U449F, U446F, D321, D216, U43F, U464 F, D318, D319, D320, U443F, U442F; and the National Heritage Institute, Brno, no. 10572 and no. 10573. For a detailed description of the chateau, see Augustinková, Kouřilová, Míčková (2017-2018).

3 Augustinková, Kouřilová, Nokkala Miltová (2019: 87-95).

4 The Kravaře estate went to the Eichendorff family through the marriage between Freiherr Jakob von Eichendorff and the daughter of Michael Sendivogius in 1636. Jakob’s great-nephew Johann Rudolf (1687-1750, from 1724 the high chamberlain of the Duchy of Krnov) took over the estate in 1708 and started to renovate it in 1721. The most essential modifications were made in 1721-1728: Samek (1990: 197-200); Augustinková, Kouřilová, Míčková (2017-2018: 17-18). 
of Juno and Jupiter at the table (Fig. 1). ${ }^{5}$ The newer interpretation of the scene and its relations to a wider context of Baroque art shall be discussed in this article.

The edition of the Metamorphoses which inspired the artists in Kravaře was a lavish print by the Nuremberg printer and publisher Johann Jacob Sandrart (1655-1698) published in Nuremberg in 1698 under the title P. Ovidii Nasonis Metamorphosis Oder Sinn-reicher Gedichte von Verwandlungen | Erster Theil | Enthaltend Die sieben Ersten Bücher | Gezieret Nicht nur allein mit Lehr-reichen | ̈̈ber jede Fabel | aus dem Französischen in das Teutsche übersetzten herrlichen Anmerckungen|Sondern auch Mit gantz neuen | über die in denenselben vorkommenden Handlungen | beygefügten Kupffer-Figuren. The edition has received little attention among researchers, and there is little evidence of its influence within the Czech milieu. ${ }^{6}$

Johann Jacob Sandrart was the son of the Nuremberg printer and publisher Jacob Sandrart and great-nephew of the famous artist and art theoretician Joachim von Sandrart (1606-1688). Johann Jacob Sandrart created an extensive graphic collection. His artistic and business activities are well documented in the estate inventory of 1698, compiled by the artist, academy director and connoisseur Georg Christoph Eimmart, Jr. (1638-1705). The estate inventory makes it clear that Johann Jacob owned an extensive, high-quality collection including items previously owned by his great-uncle Joachim. ${ }^{7}$

The creation of his 1698 edition of the Metamorphoses was a remarkable process, given the family background. Sandrart's sumptuous edition followed the heritage of his famous great-uncle Joachim and his commented translation of Ovid's Metamorphoses into German, which was included in the 2nd volume of Joachim Sandrart's Teutsche Academie. The first volume was published in Nuremberg in 1675, and received much acclaim, which encouraged Sandrart to instigate the creation of a second volume. Published in Nuremberg in 1679 by Christian Sigismund Froberger, ${ }^{8}$ the second volume was inspired by a Dutch version of the Ovidian commentary written by the Haarlem painter and art theoretician Carel van Mander (1548-1606). ${ }^{9}$ Joachim attempted to make improvements to the text, but his efforts were ended by his death. ${ }^{10}$ Johann Jacob Sandrart's edition was

5 Hlubinka (1971: 65-74 and 1973: 98-104).

6 The only other example known to the author is the stucco ceiling in one of the rooms of the chateau in Velké Hoštice.

7 Peltzer (1925); Vollmer (1935: 398-399); Von Hagen, Tacke (2005: 428-429); Grieb (2007: 1295). The work of Johann Jacob Sandrart is rarely described in literature (with the exception of reference works), on his work, see e.g. Hoffmann (1994: 65-71); Gerst (2000: 23-25).

8 The commentary on the Metamorphoses is entitled P. Ovidii Nas. Metamorphosis, oder Des verblümten Sinns der Ovidianischen Wandlungs-Gedichte gründliche Auslegung: Aus dem Niederländischen Carls von Mander Zu Behuf der Edlen Poesie-Kunst und Tugend Liebhabere ins Teutsche übersetzt, Und der Sandrartischen Academie enverleibet.

9 Carel van Mander valued the Metamorphoses greatly. His Het Schilder Boeck includes an independent commentary on the Metamorphoses (Uytleggingh op den Metamorphosis Pub. Ovidii Nasonis. Alles streckende tot voordering des oronnen en eerlocken Vorgherlycken wandels. Seer dienstich den Schilders, Dichters, en Const-beminders. Oock yeghelyck tot leeringh by een ghebracht en geraemt Door Carel van Mander Schilder). Mander's interpretation of the myths combines three levels: euhemeristic ("gheschiedighe"), astro-psychological ("natuerlijcke") and moral ("leerlijcke"). On Mander's commentary, see esp. Sluijter (1986: 295-321); Miedema (1973: 653-668).

10 Teutsche Academie by Joachim von Sandrart was later printed in 1768-1775 in a new eight-volume edition by Johann Jacob Volkmann who obtained Sandrart's matrixes. The commentary on the Metamorphoses is accompanied with engravings by Johann Jacob Sandrart and Christian Engelbrecht, but the text is different because Volkmann considered the original translation outdated. He used short 


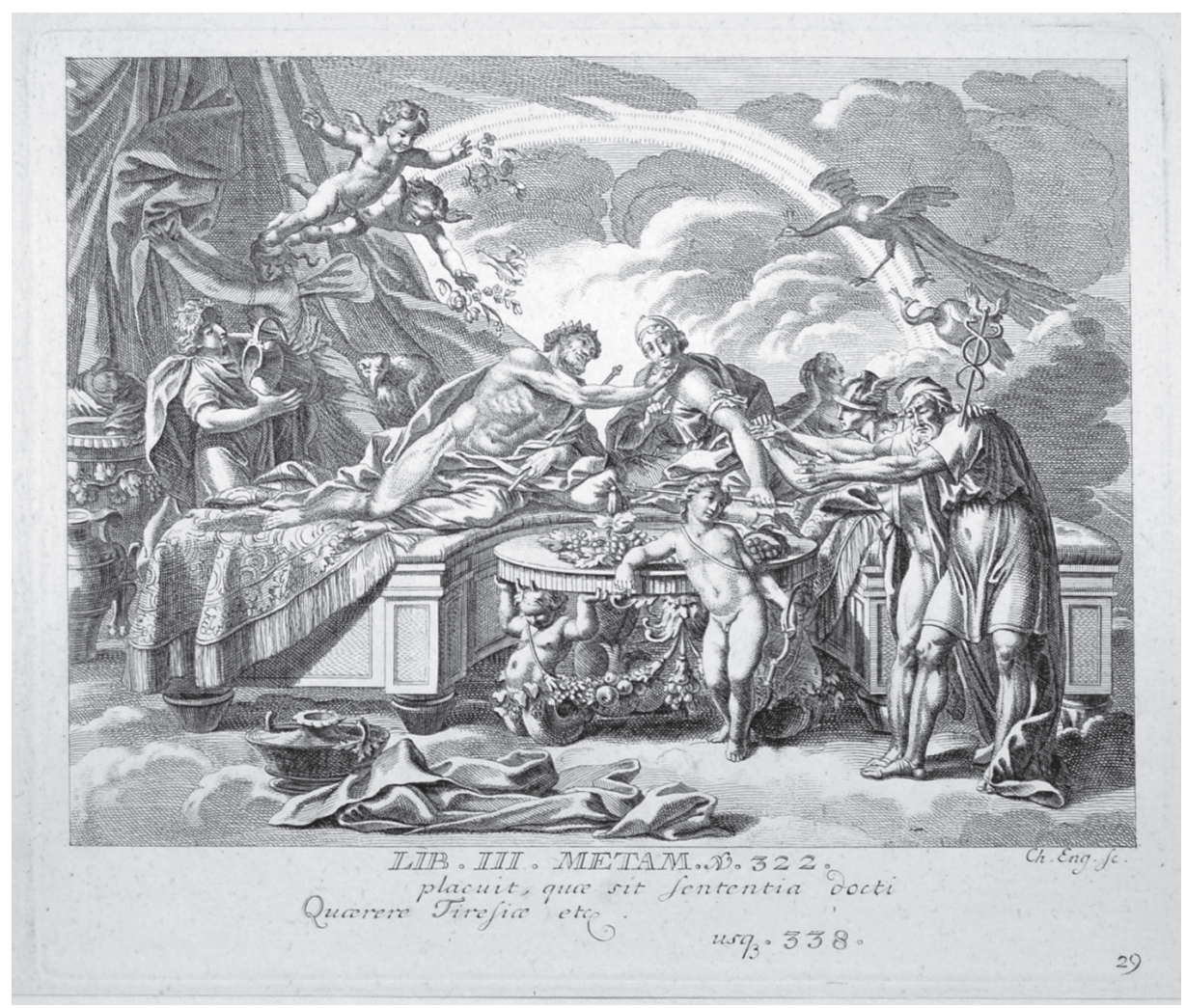

Fig. 2: Judgement of Tiresias, engraving from edition of Ovid's Metamorphoses by Johann Jacob Sandrart, Nürnberg, 1698.

a long-running project, too. Most engravings for the book were created by Christian Engelbrecht (1672-1735) based on Sandrart's drawings, but some graphic representations were the work of Johann Jacob's son, Lorenz. ${ }^{11}$ Due to his early death, Johann Jacob Sandrart's work remained incomplete and only managed to cover the myths up to the beginning of Book VII. Some of the detailed, vivid and inventive pictures in Sandrart's edition relate to less visualized Ovidian stories which were not included in older editions (e.g. Bacchus nursed by the nymphs or Clytie turning into a sunflower). This is reflected in the decorations of the Kravaře chateau, especially the ceiling of the grand hall which shows the rare story from Book III of the Metamorphoses about the prophet Tiresias (Fig. 2).

explanatory commentaries, loose translations of the French Explications historiques by Abbé Banier into German. On the genesis of these commentaries, see esp. Die Metamorphosen des Ovid (2000: 50-54); Thimann (2007: 28-29).

11 The matrixes and ready-to-use graphic compositions are mentioned in the estate inventory of Johann Jacob von Sandrart. Among the sketches and engravings in the workshop (Kupfer-Cammer), one item reads: Lit. E Mehr ein großes Buch mit zwey Hundert fünf und sechzig Handrißen, in Landschaften und Ruinen bestehend, umb Die Original-Handriße über den Ovidium, von Johann Jacob de Sandrart: Peltzer (1925: 156). 
Ovid used Tiresias's story to introduce the tale about Narcissus who was connected with the royal house of Thebes. Tiresias was called to judge a dispute between Juno and Jupiter triggered by the chief god's teasing remark that women experience greater enjoyment (maior voluptas) during sexual intercourse than men. ${ }^{12}$ The gods chose Tiresias to judge their dispute because he had both male and female experience. The story has it that one day Tiresias saw two snakes coupling. Frightened, he killed the female with his walking stick and consequently changed into a woman. He spent seven years in his female body. To reverse the unwelcome change, he looked for two coupling snakes again. When he finally found them, he killed the male, and returned to his male body. When asked to judge the dispute, he decidedly ruled that women enjoy sexual intercourse more than men. Juno took her revenge on him by taking away his sight. Since gods could not reverse decisions of other gods, Jupiter compensated his hardship by giving him prophetic vision. Tiresias became a famous prophet and Narcissus's mother Liriope contacted him to discuss her son's future.

Ovid's version of the story was inspired by the pseudo-Hesiodic Melampodia, but there are also alternative stories, including a rare version offered by Pherecydes (6th century BCE), later adopted by Callimachus (310/305-ca 240 BCE) in his 5th hymn, which says that Tiresias saw Minerva bathing, the goddess accidentally blinded him when she tried to cover his eyes with her hand, and then gave him the prophetic powers as compensation. ${ }^{13}$

Tiresias's prophecies then became a part of the story of Thebes: he established that the plague which affected Thebes during Oedipus's rule was caused by Oedipus's marriage to his own mother; he advised King Creon to sacrifice his son in order to end the siege of Thebes; and, ten years later, he told the Thebans to leave the town when he had foreseen its fall, but then he intentionally stayed behind because he saw his own death approaching. In the underworld, according to Homer, Tiresias advised Odysseus how to get back to the shores of Ithaca. ${ }^{14}$ In the Roman epic poem Thebaid by Publius Papinius Statius (ca 45-ca 96) about the fall of Thebes, Tiresias and his daughter, the prophet and priestess Manto, stage the summoning of dead spirits upon a request from the young Theban king Eteocles.

Tiresias's adventures were rarely depicted in early modern art, regardless of the source text. The last mentioned scenes related to Statius's Thebaid, the summoning of dead spirits by Tiresias or Tiresias and Manto, can be found in paintings by the Amsterdam painter Domenicus van Wijnen (1658-1700), ${ }^{15}$ but his works are an exception in 17 th century art. Visual representations of Ovid's version of the story of Tiresias are generally limited to the illustrations used in various editions of his Metamorphoses, most often picturing Tiresias killing the coupling snakes with his stick or transforming into a woman. ${ }^{16}$ The

12 For an analysis of the Judgement of Tireisias in Ovid's poetry, see e.g.: Coleman (1990: 571-577); Balsley (2010: 13-31).

13 Nagle (1984: 239-240); O’Hara (1996: 174-176).

14 Reid (1993: 1031-1033).

15 Salomonson (1985: 114). The painting of Tireisias summoning dead souls is kept in the collection of Staatliche Kunstsammlungen in Kassel; the painting of Tireisias and Manto summoning dead souls is kept in the collection of Herzog Anton Ulrich Museum in Braunschweig.

16 In addition to the editions mentioned further in this text, illustrations of this part of Tireisias's story are included for instance in the 16th-century Venice editions with commentaries by Lodovico Dolce, illustrated by G. A. Rusconi. 


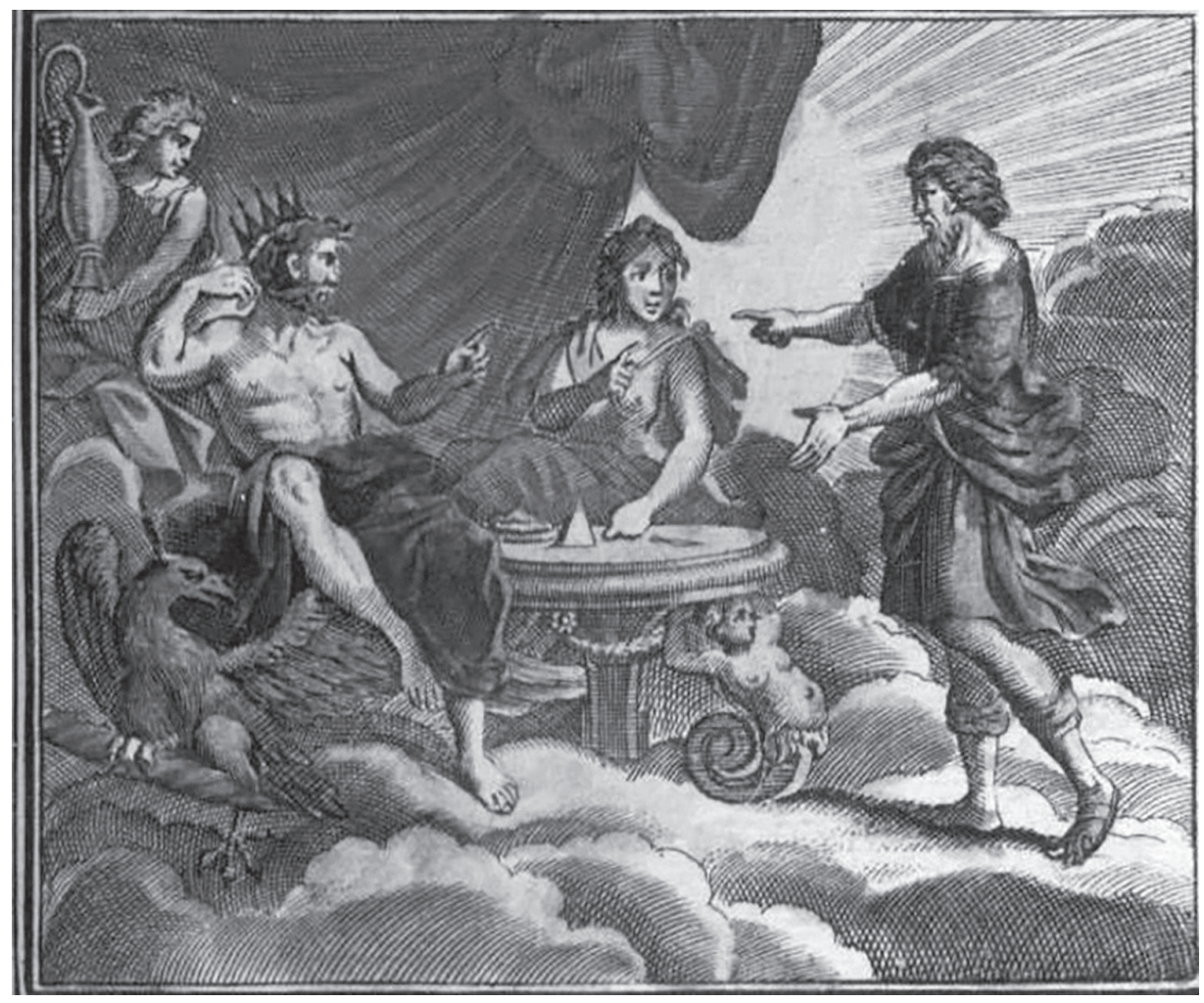

Fig. 3: Sébastien Le Clerc - François Chauveau, Judgement of Tiresias, engraving from Métamorphoses d'Ovide en rondeaux, Paris, 1676.

motif of Tiresias's judgement appeared in Sandrart's edition and two more illustrated cycles; the first by the Dutch engraver Hendrick Goltzius (1558-1618), whose workshop published 52 engravings up to Book IV of the Metamorphoses between 1589 and 1615;17 the second was a richly illustrated French edition published in Paris in 1676 and titled Métamorphoses d'Ovide en rondeaux. The engravings were created by Sébastien Le Clerc (1637-1714) and François Chauveau (1613-1676) (Fig. 3). Comparing the three consecutive depictions of Tiresias's judgement (Goltzius - Le Clerc and Chauveau - Sandrart), Sandrart's representation of the iconographic theme is clearly the most complex one; it is a grandiose multi-figure scene. Sandrart was the only artist who included the motif of Tiresias's blinding; Tiresias is groping in the dark guided by Mercury. The comparison makes it clear that Sandrart was inspired by the French engraving and developed its concise structure into a lavish visual composition.

In addition to the narrative component visualised by the illustration, it is interesting to look at the contemporaneous explanations of Tiresias's judgement, which take very diverse courses, from moral messages to astrological implications. The interpretation in Sandrart's edition dedicated ample attention to the latter, stating that Tiresias judged two

17 Hollstein (1953: 16-67); Leesberg (1993: no. 260.578 I). 
gods who represent two elements - Jupiter stands for the fire, Juno for the air. With this in mind, Tiresias's judgement seems understandable because plants need air rather than fire and moisture rather than heat to reproduce:

Tiresias zum Richter erkohren worden | um zwischen zweyen Gottheiten den Gereit zu entscheiden $\mid$ ob der Mann oder das weib in den liebes-Wercken die mehreste Ergötzung empfinde | so wird durch diese zwey Gottheiten verstanden das Feuer und die Luff. Jupiter bedeutet das Feuer | und Juno die Lufft.

Auch ist das Urtheil Tiresioe hierinnen nicht unrecht $\mid$ da er den Ausspruch gethan $\mid$ da $\beta$ an den Wercken der Generation die Juno am mehresten Lust habe | dann die Zeit hat viel Experimenta gelehret $\mid$ daß zur Hervorbringung der Pflanzen und Gewächse | zweymalso viel Lufft als Feuer erfordert werde $\mid$ oder um es verständlicher zu geben $\mid$ nochmal so viel Feuchtigkeit als Hitze. ${ }^{18}$

Sandrart asserts that Juno blinded Tiresias to show him that the air (which she represented) gets thicker with fog and clouds in the winter, eventually becoming dark and impenetrable to sight. Jupiter then replaced Tiresias's bodily sight with prophetic one, representing the sun which gains power as the winter passes, ultimately breaking through the fog and clouds and bringing the earth to life again. Also, a skilled farmer can tell from the fields and trees in the winter what weather he can expect the next year:

Endlich wird in eben dieser Fabel gemeldet $\mid$ daß Juno den Tiresiam aus die Letze habe blind gemacht | um zu zeigen $\mid$ da $\beta$ die Lufft | welche unter dem Namen der Juno verstanden wird | in dem Winter sic hmit Nebel und Wolcken verdicket | und dadurch die Zeit ganz finster | trüb und blind machet.

Mann nun ferner gedichter wird $\mid$ da $\beta$ Jupiter an statt der leiblichen Augen $\mid$ die Tiresias verloren $\mid$ ihm die Augen des Verstands geöffnet $\mid$ so will man damit so viel sagen $\mid$ da $\beta$ die Sonne | welche in dem Winter anfängt sich wieder gegen uns zu nähern | und die Wolcken und Nebel $z$ u vertreiben $\mid$ der Zeit die Krafft mittheilet $\mid$ da $\beta$ sie die Erde wieder lebendig machet $\mid$ damit sie die Sachen | die in ihr stecken | hervorbringen kan; oder vielmehr will man dadurch anzeigen $\mid$ daß man an der Beschaffenheit des Winters urtheilen könne | was man hernach vor ein Jahr $\mid$ ob es fruchtbar oder unfruchtbar $\mid z$ erwarten habe. Dann wer nur den Feldbau ein wenig verstehet $\mid$ der wei $\beta$ da $\beta$ man in dem Winter an den Bäumen |Stäuten | und andern Dingen sehen könne | wie die Witterung des folgenden Jahrs beschaffen seyn werde. ${ }^{19}$

Sandrart also refers to Lucian of Samosata's treatise Astrology which includes a different interpretation of the myth. The author says that Tiresias was a distinguished astrologer who used to be both male and female, which taught him that the differences between the sexes are caused by the planets. Another author, according to Sandrart, believed that Tiresias was a hermaphrodite. Sandrart concluded that Tiresias was initially a proper man who did many praiseworthy deeds, but later, through extensive indulgence in lechery, became too effeminate to be respected more than a woman:

Sonsten finden man auch in Luciano, wiewol nur in zwey oder drey Worten | noch eine andere Auslegung von dieser Fabel: Dann dieser Author saget | da $\beta$ Tiresias ein grosser Astrologus

18 Ovidius (1698: 50).

19 Ovidius (1698: 50). 
gewesen seye | man habe aber von ihm gedichtet $\mid$ daß er so wol ein Mann als Weib gewesen | um willen er gelehrt $\mid$ da $\beta$ der Unterscheid des Geschlechts allein von dem Einflu $\beta$ der Planeten herrühre. Ein anderer Author hat diese Fabel mit noch weniger Worten ausgelegt | und vermeint | Tiresias seye ein Hermafrodit, das ist $\mid$ zu gleich männ-und weiblichen Geschlechts gewesen. Ausser dem aber möchte man auch auf die Gedancken kommen $\mid$ da $\beta$ diese Fabel auf Veranlassung der Sitten des Tiresioe, also seye ersonnen worden; Anfänglich habe man ihn vor einen rechtschaffnen und braven Mann gehalten | wegen seines guten Lebens und ansehnlicher Thaten die er verrichtet | hernachmal aber habe er sich den Wollüsten ergeben | und seye dadurch so Weibisch worden $\mid$ daß man ihn vor nicht viel besser als ein Weib geachtet. ${ }^{20}$

Johann Jacob Sandrart's passage about Tiresias's judgement is completely different from Carel van Mander's interpretation (from his His Het Schilder Boeck), which was used by Joachim von Sandrart for his commented edition of the Metamorphoses (published in 1679 by Christian Sigismund Froberger). Although Joachim's and Johann Jacob's editions are often seen as related, the differences between both texts indicate that Johann Jacob's version was influenced by Mander's interpretation, and consequently Joachim's translation, much less than usually assumed. ${ }^{21}$ Joachim's explanation of the story of Tiresias soon departs from Ovid's version, and with reference to Hyginus's Fabulce maintains that Jupiter prolonged Tiresias's life by seven generations. Then he includes a variant of the story of Tiresias's blinding by Minerva, which leads to a moral: By seeing a naked goddess, Tiresias experienced the sweetness of real insight, and therefore desired other things; because when we see divine wisdom, it leaves us blind and confronted with our own ignorance; but when we struggle to continue our search for wisdom, we gain a better insight into the things that are to come:

Den Wahrsager Tiresias $\mid$ weil er blind gewest $\mid$ haben wir $\mid$ im dritten Buch $\mid$ stillschweigend vorbey gegange | ietzo aber gibt uns seine Tochter Manto | voll vom Weissager-Geiste im Einladen zum Opffern der Latona $\mid$ Anlaß | seiner zugedencken. Von deme $\mid$ daß er Mann und Weib gewest seyn soll | lieset man | im dritten Buch der Verwandlung unsers Poeten | und warum dem armen Manne von der Juno das Gesicht benommen | und vom Jupiter die Gabe des Weissagens gegeben worden. Eben dieses wird auch vom Hyginius | im 75. Capitel seiner Fabeln | also beschrieben | daß er annoch beyfüget | wie der Jupiter | ̈̈ber die Gabe der Weissagun | ihme auch das Leben | bis auf sieben Menschen Alterthum | erlängert habe. Es wird aber sonsten auch eine andere Ursach seiner Blindheit erzehlet: weil nemlich die keuschreine Minerva | mit andren | gantz mutternacket sich gebadet | in dem Heliconischen Brunn/ Tiresias wird von Minerva blind gemacht: weil er sie nacket gesehen. Hippocrene| und vom Tiresias allda unversehens nacket gesehen worden sey | welches sie so übel empfunden und aufgenommen/ daß sie ihm seins Gesichts beraubt habe: Dann ihr nicht ziemlich zu seyn bedünckte $\mid$ daß sich ein sterblicher Mensch rühmen solte | er hätte sie | die doch für ihre Ehre so sorgfältig war |nacket gesehen: Jedoch habe Chariclo | des Tiresias Mutter|von der Minerva erlangt/ daß er | an statt seines auswendigen Gesichts | ein inwendiges | nemlich zukünfftige Dinge vorzusagen |Lehrliche Auslegung über des Tiresias blindheit. bekommen. Hierinn nun einen verständlichen Sinn zu finden/ ist zu wissen | daß bey dem nackend sehen der Minerva angedeutet werde/ wie derjenige | so die Süssigkeit der rechten Weisheitsfrucht nur einmal geschmeckt | oder die Klarheit derselben eins recht gesehen | die Augen seiner Sinnen | alle

20 Ovidius (1698: 50).

21 On the mutual links, see esp. Die Metamorphosen des Ovid (2000: 50-54). 
andere Dinge zu wünschen | oder zu begehre | willig zu zuschliessen pflege; oder daß wir | wann wir gründlich betrachten | was die Göttliche reine Weisheit sey | befinden und bekennen müssen $\mid$ daß wir von uns selber blind und unverständig seynd | und gar nichts wissen. Wenn wir ihr aber mit Fleiß nachspüren und dieselbe ernstlich suchen|bekommen wir ein besser Gesicht $\mid$ durch welches unser Geist $\mid$ mit ihrer Erkändnus | erleuchtet wird | daß wir alsdann zukünffige Dinge deuten $\mid z u$ vor sehen und sagen können. Sintemal wir alsdann weislich überlegen | was auf diese | oder jene weise vorfallen | oder geschehen könte. Nunmehro wird vonnöhten seyn/ auch den Amphion vor die Hand zu nehmen. ${ }^{22}$

If we compare the above-mentioned variants of Tiresias's judgement with the explanations of leading mythographers, we can see that the explanations must have influenced Carel van Mander and consequently Joachim Sandrart. Natale Conti's Mythologiae, for instance, offers both alternative stories - about Minerva and about the dispute between Juno and Jupiter - and the lines of reasoning display marked similarities with the interpretations presented above:

Tiresias l'apperceut; ce qu'elle prit en si mauaise part qu'elle luy'fit perdre laveuë, faisant estat n'estre aucunemèt raisonnable qu'vn homme mortel osast se v'ter d'auoir veu Minerue nuë, \& se baignant. Toutefois Chariclo mere dudit Tiresias obtint d'elle à force de prieres, qu'au lieu des yeux corporels dōt elle l’auoit priué, il luy pleust le recompenser d'vne veuë spirituelle, \& luy dōner le don de prophetie pour deuiner les choses à venir [...] Toutefois Hygin au 75. chap. Des fables nous dōne vn autte sujet de l'aueuglement de Tiresias: [...] Mais Iupiter en recompense luy prolongea sa vie iusqu'à sept aages d'hommes, \& luy ottroya par mesme moyé l'esprit de propethie par dessus tous autres mortels. ${ }^{23}$

The distance of the textual and visual component of Johann Jacob Sandrart's Metamorphoses from its sources of inspiration, as well as the influence of this edition in 18th century art, deserves more research in future. The example of Judgement of Tiresias clearly shows that although Joachim Sandrart's and Johann Jacob Sandrart's commentaries have not been thoroughly compared yet, it is clear that they differ considerably. ${ }^{24}$ It also remains unclear why the Judgement of Tiresias was chosen for the ceiling decoration in the grand hall of the Kravaře Chateau in the 1720s, and what message it was intended to convey. Although it is hard to tell whether it was the moral or astrological implications that played the main role, we can infer from the motifs depicted in other rooms of the chateau, mainly romantic scenes with astrological allusions, that it was rather the astrological explanation, which was also accented in Johann Jacob Sandrart's commentary. In other rooms of the chateau there were following scenes: Venus and Adonis, Cephalus

22 Ovidius (1679: 73).

23 Le Comte (1611: 282-283).

24 The inventory of Johann Jacob Sandrart makes it clear that he had access to Joachim's texts, including the translation of the Metamorphoses. See Peltzer (1925: 159).

The title of Johann Jacob Sandrart's edition of the Metamorphoses indicates that it is a translation from French, but the source has not been identified yet. It could be the edition by Michel de Marolles, as his commentary of Ovid's work was listed in Sandrart's inventory. Although the list only offers a vague note Der Ovidius, von Michel de Marolles (Peltzer 1925: 160), it could be the commentary published in 1677 and titled Les Métamorphoses d'Ovide comprises en quatre vers pour chaque fable des 15 livres de cet ouvrage ou plus tôt pour leur servir d'argument. Still, it seems undisputable that Johann Jacob Sandrart used more source texts for his commentary. 
and Procris, Venus and Pluto, Rape of Proserpine, Rape of Europe and Juno putting Argus's eyes on peacock's tail. Sandrart compares, in accordance with other authorities, one hundred eyed Argus with the night sky full of stars. Destiny of Adonis and Proserpine represents traditional example of cyclical course of seasons of the year in nature. ${ }^{25}$ Therefore, it was no wonder that Venus and Adonis depiction was surrounded by allegorical compositions of seasons of the year.

Natural-allegorical (astrological) connotation of mythological stories belonged to widely used early modern iconography where depictions of elements, seasons of the year, planets or phases of the day were integral part of the decorations. References to the nature cycles had become a metaphorical allusion to eternal glory of the celebrated family. It is beyond doubt that that these metaphorical allusions were carved in order to reinforce the high social status of High Chamberlain (Oberstlandkämmerer) Jan Rudolph Francis count of Eichendorff, who commissioned the decorations. ${ }^{26}$

The ceiling in the grand hall in Kravaře was a rare phenomenon in Baroque art, because the motif of Tiresias's judgement was very rare in early modern iconography, and it has never appeared in monumental artistic compositions. Its exceptionality was underlined by its prestigious location on the ceiling in the grand hall of the seat of the Eichendorffs. The stucco ceiling in Kravaře was the only known visual representation of this motif not only in the Central European context, but most probably in all Europe.

\section{REFERENCES}

Augustinková, L., Kouřilová, D., Míčková, K., 2017-2018. Stavebně historický průzkum zámku v Kravařích [Historical Building Survey of Chateau in Kravaře]. Manuscript (available in Town Office in Kravaře). Augustinková, L., Kouřilová, D., Nokkala Miltová, R., 2019. Zámek Kravaře. Barokní klenot Horního Slezska [Chateau in Kravaře: Baroque jewel of Upper Silesia]. Kravaře: Město Kravaře.

Balsley, K., 2010. 'Between Two Lives: Tiresias and the Law in Ovid's Metamorphoses'. Dictynna: Revue de poétique latine $7,13-31$.

Coleman, K. M., 1990. 'Tiresias the Judge: Ovid, Metamorphoses 3.322-38'. The Classical Quarterly 40, 571-577.

Le Comte, N., 1611. Mythologie, c'est à dire, Explication des Fables, contenant les genealogies des Dieux, les cerimonies de leurs sacrifices, Leurs gestes, adventures, amours, Et presque tous les preceptes de La Philosophie, naturelle, \& moralle [...]. Rouen: [Jean Ofmont / Manassez de Preaulx / Jacques Besongne].

Die Metamorphosen des Ovid, 2000. Die Metamorphosen des Ovid. Graphiken nach einem Klassiker antiker Dichtung. Anhaltische Gemäldegalerie Dessau, Graphische Sammlung, 4. November 2000 - 7. Januar 2001. Dessau: Anhaltische Gemäldegalerie.

Gerst, D., 2000. Drucke des höfischen Barock in Schweden. Der Stockholmer Hofmaler David Klöcker von Ehrenstrahl und die Nürnberger Stecher Georg Christoph Eimmart und Jacob von Sandrart. Berlin: Gebr. Mann Verlag.

Grieb, M. (Hrsg.), 2007. Nürnberger Künstlerlexikon. Bildende Künstler, Handwerker, Gelehrte, Sammler, Kulturschaffende und Mäzene vom 12. bis zur Mitte des 20. Jahrhunderts. München: K. G. Saur Verlag.

Von Hagen, F., Tacke, A., 2005. 'Sandrart, Johann Jacob'. In: Neue Deutsche Biographie. Band 22. Berlin: Verlag Duncker \& Humblot, 428-429.

25 Ovidius (1679: 19-21, 88-91).

26 On the family of Eichendorff, see Weltzel, Heiduk (1992). 
Hlubinka, M., 1971. 'Otázky kolem obnovy kravařského zámku’ [Questions about renovation of Chateau in Kravaře]. Sborník památkové péče v Severomoravském kraji 1, 65-74.

Hlubinka, M., 1973. 'Ke stavebně historickému vývoji zámku v Kravařích' [To historical building development of Château in Kravaře]. Sborník památkové péče v Severomoravském kraji 2, 98-104.

Hoffmann, D., 1994. 'Arminius und Germania-Thusnelda. Zu einem „annehmlichem Kupfer“ von Johann Jacob von Sandrart'. In: S. Schade-Tholen, M. Wagner, S. Weigel (Hrsg.), Allegorien und Geschlechterdifferenz. Köln: Böhlau Verlag, 65-71.

Hollstein, F. W. H., 1953. Dutch and Flemish etchings, engravings and woodcuts: ca. 1450-1700. Vol. 8. Amsterdam: Menno Hertzberger.

Leesberg, M., 2012. The New Hollstein Dutch \& Flemish etchings, engravings and woodcuts 1450-1700. Hendrick Goltzius. Vol. III. Oudererk aan der Ijssel [et al.]: Sound \& Vision Interactive [et al.].

Miedema, H., 1973. 'Karel van Mander's Grondt Der Edel Vry Schilder-Const ("Foundations of the Noble and Free Art of Painting")'. Journal of the History of Ideas 34, 653-668.

Miltová, R., 2009. Mezi zalíbením a zavržením. Recepce Ovidiových Metamorfóz v barokním umění $v$ Čechách a na Moravě [Between pleasure and damnation: The reception of Ovid's Metamorphoses in Baroque art in Bohemia and Moravia]. Brno: Barrister \& Principal.

Nagle, B. R., 1984. 'Amor, Ira and Sexual Identity in Ovid's Metamorphoses'. Classical Antiquity 3, 239240.

Nokkala Miltová, R., 2016. Ve společenství bohů a hrdinů. Mýty antického světa v české a moravské nástěnné malběšlechtických venkovských sídel v letech 1650-1690 [In the society of gods and heroes: Myths of the classical world in Bohemian and Moravian wall paintings in aristocratic rural seats over the years 1650-1690]. Praha: Nakladatelství Lidové noviny.

O'Hara, J. J., 1996. 'Sostratus Suppl. Hell. 733: A Lost, Possibly Catullan-Era Elegy on the Six Sex Changes of Tiresias'. Transactions of the American Philological Association 126, 173-219.

Ovidius, 1679. P. Ovidii Nas. Metamorphosis, Oder Des verblümten Sinns der Ovidianischen Wandlungs-Gedichte gründliche Auslegung: Aus dem Niederländischen Carls von Mander Zu Behuf der Edlen Poesie-Kunst und Tugend Liebhabere ins Teutsche übersetzt. Und der Sandrartischen Academie enverleibet. Nürnberg: Christian Sigismund Froberger.

Ovidius, 1698. P. Ovidii Nasonis Metamorphosis Oder Sinn-reicher Gedichte von Verwandlungen. Erster Theil. Enthaltend Die sieben Ersten Bücher. Gezieret Nicht nur allein mit Lehr-reichen über jede Fabel aus dem Französischen in das Teutsche übersetzten herrlichen Anmerckungen Sondern auch Mit gantz neuen über die in denenselben vorkommenden Handlungen beygefügten Kupffer-Figuren Inventiret und heraus gegeben von Johann Jacob von Sandrart. Nürnberg: [Sandrart].

Peltzer, R. A., 1925. 'Sandrart-Studien'. Münchner Jahrbuch der bildenden Kunst 2, 103-165.

Reid, J. D., 1993. The Oxford guide to classical mythology in the arts, 1300-1990s. Oxford: Oxford University Press.

Salomonson, J. W., 1985. 'Dominicus van Wijnen. Ein interessanter „Einzelgänger“ unter den niederländischen Malern des spaten 17. Jahrhunderts'. Niederdeutsche Beiträge zur Kunstgeschichte 24, 105-170.

Samek, B., 1999. Umělecké památky Moravy a Slezska II [Artistic Monuments of Moravia and Silesia]. Praha: Academia.

Sluijter, E. J., 1986. De 'heydensche fabulen' in de Noordnederlandse schilderkunst, circa 1590-1670. Een proeve van beschrijving en interpretatie van schilderijen met verhalende onderwerpen uit de klassieke mythologie. Hague: E. J. Sluijter.

Thimann, M., 2007. Gedächtnis und Bild-Kunst. Die Ordnung des Künstlerwissens in Joachim von Sandrarts Teutscher Academie. Freiburg i.Br. / Berlin / Wien: Rombach.

Vollmer, H. (Hrsg.), 1935. Allgemeines Lexikon der bildenden Künstler. Von der Antike bis zur Gegenwart. Band 29. Leipzig: E. A. Seemann.

Weltzel, A., Heiduk, F., 1992. Geschichte des edlen und freiherrlichen Geschlechts von Eichendorff. Sigmaringen: Thorbecke. 


\title{
RECEPCE ILUSTROVANÝCH VYDÁNÍ OVIDIOVÝCH METAMORFÓZ V ČESKÉM A MORAVSKÉM UMĚNÍ. JOHANN JACOB VON SANDRART A SOUD TEIRESIŮV
}

Jedním ze základních znaků barokního umění v Čechách a na Moravě je jeho receptivní charakter. $\mathrm{V}$ př́ípadě př́běhů čerpajících $\mathrm{z}$ textu Ovidiových Metamorfóz umělci využívali zejména populární ilustrované edice Ovidiova díla. Př́íspěvek se zabývá vzácným dokladem recepce edice Metamorfóz publikované J. J. von Sandrartem v Norimberku roku 1698. Precizní a živé rytiny této edice ilustrují i méně obvyklé ovidiovské prríběhy, což se odrazilo též ve výzdobě zámku v Kravařích, která byla nenávratně zničena při požáru roku 1937. Objev grafické předlohy napomohl určit všechny ikonografické motivy někdejší výzdoby Kravař. Strop hlavního sálu kravařského zámku zdobil výjev líćící osudy slavného proroka Teiresia a vedle př́běhu samotného se příspěvek věnuje dobovým vizuálním reprezentacím a výkladům Teiresiova soudu. Kravařský hlavní sál však reprezentoval mnohem podstatnější fenomén barokního umění, nebot motivy Teiresiova soudu náleží mezi zcela raritně se vyskytující raněnovověkou ikonografii, která se v monumentálních uměleckých zakázkách neobjevuje vůbec. Kravařský štukový strop tak zastupoval dosud jediné známé znázornění tohoto prríběhu nejen v kontextu středoevropském, ale patrně i evropském.

\author{
Radka Nokkala Miltová \\ Masaryk University, Brno \\ miltova@phil.muni.cz
}

